\title{
Evaluation of Manure Types in Improving the Performances of New Maize Hybrids in Coastal Land
}

\author{
Rustikawati", E. Suprijono, B.G. Murcitro, B.A.Y. Manulang and C. Herison \\ Department of Crop Production, Faculty of Agriculture, University of Bengkulu. \\ Jln W.R. Supratman, Kandang Limun, 38371, Bengkulu \\ "Corresponding author.e-mail: rustikawati@unib.ac.id
}

\begin{abstract}
Coastal land has great potential for the expansion of agricultural land. However, its productivity is generally low due to its highly sandy texture, resulting in low nutrient status and limited water absorption capacity. Maize yield is relatively sensitive to low nutrient and water availability. The application of manure in the coastal land management is a promising effort to overcome these obstacles through the improvement of physical, chemical, and biological properties of the soil. The effects of type of manure on growth and yield of four maize hybrids have been assessed. A factorial $4 \times 4$ experiment arranged in a fully randomized block design with 2 factors and 3 replications was conducted on the coastal land to determine (1) the best types of manure for maize production in the coastal land and (2) the most adapted hybrid maize to coastal land. The first factor was maize hybrids consisted of CT16, CT30, CT34, and CT50. The second factor was the manure types consisted of control (without fertilizer), poultry manure, cow manure, and goat manure. The results showed that there was no interaction between hybrid and manure type. The most adaptable maize hybrid to coastal land was CT50. The most suitable fertilizer to increase maize productivity in coastal countries was goat manure.
\end{abstract}

Keywords: maize, manure, coastal land

\section{INTRODUCTION}

Maize (Zea mays L.) is the third most economically cultivated crop in Asia after rice and wheat. Worldwide, maize is the most commonly grown cereal crop [1]. The nutrient content of maize consists of essential fatty acids, isoflavones, essential minerals $(\mathrm{Ca}, \mathrm{Mg}, \mathrm{K}, \mathrm{Na}, \mathrm{P}$, and $\mathrm{Fe}$ ), anthocyanins, beta-carotene (pro vitamin $\mathrm{A}$ ), and essential amino acids [2] The high carbohydrate content makes maize is very suitable for raw materials of feed and industry [3]. The national demand for maize grain in Indonesia is increasing year by year which lead to increase of import of maize, especially for animal feed and industry. In the year of 2018 [4 Statistic Indonesia], Indonesia imported up to 730,918 tons of maize grain for animal feed. This figure has decreased considerably compared to the previous years. Therefore, an increase in production is necessary to fulfill the domestic demand for maize.

National maize production could be increased by the use of superior hybrid cultivars. In comparison to open-pollinated or composite cultivars, the yield potential of hybrid cultivars is considerably higher [5]. Meanwhile, hybrid seeds available on the market today are mostly imported. The dependence on imported seed hinders the increase in production. Variety development is expected to overcome many problems of maize production in Indonesia [6]. We have developed some hybrid cultivars of maize adaptive to acid soils [7]. The hybrids were single crosses of the sixth inbred generation (S6) of gamma-irradiated mutants [8].

Besides boosting the crop productivity, increasing national maize production can also be achieved by expanding the planting area. However, due to land conversion for non-agricultural purposes, the fertile land is lessened, and the remaining available is dominated by marginal land. One of highly potential marginal lands in Indonesia is coastal land.

The coastal areas of Indonesia cover about $1,060,000$ ha and spread over 106,000 km long of the coastline. The land is sodic/alkaline saline [9]. The coastal land is generally poor in organic matter, total $\mathrm{N}$ content and the available P-state. The low $\mathrm{N}$ content can be attributed to the low organic matter content [10].

Efforts to increase the productivity of maize in coastal lands are by providing organic materials. Generally, the physical, chemical and biological properties are improved when manures were incorporated into soils [11]. Several studies have shown the beneficial effects of animal manure on soil structural quality by reducing bulk density, increasing porosity, water infiltration rate, and saturated hydraulic conductivity $[12,13]$. Organic manure stabilizes crop production via improving soil water-nutrient condition [14]. Cow manure improves soil organic matter $(\mathrm{SOM})$, nitrogen $(\mathrm{N})$, phosphorus $(\mathrm{P})$, and soil permeability in a dry-land sandy soil [15]. The application of chicken manure on sandy soil with low fertility can 
increase vegetative growth, yield, and the quality of tomatoes [16]. Farhad, et al. [17] found that 12 tons.ha $^{-1}$ of chicken manure could increase plant height, number of rows per cob, number of grains per row, 1000-grain weight, grain yield, biological yield and harvest index of maize. Increased yield of maize also occurred with the application of cow [18] or goat manure [19].

\section{MATERIALS AND METHODS}

The study was conducted on the typical coastal land of Bengkulu, Indonesia in the year of 2020. The experimental site was situated on about $100 \mathrm{~m}$ from the sea shore.

The experiment was arranged in a $4 \times 4$ factorial randomized block design with three replications. The first factor was maize hybrid genotype consisting of CT16, CT30, CT34, and CT50. The second factor was type of manure i.e. control (without manure), poultry manure, cow manure, and goat manure. Manure was applied as much as 20 tons $\mathrm{ha}^{-1}$ at a moisture content of $18 \%$..

The field was prepared manually using a hoe to clean from weeds and roots. The experimental unit was a $3 \mathrm{~m} \mathrm{x} 2.5 \mathrm{~m}$ plots consisting of 40 plants, and between plots were spaced $50 \mathrm{~cm}$ apart. The distance between blocks was 1.5 $\mathrm{m}$.

The manure was broadcasted on the soil surface, and then was mixed thoroughly with the top layer of soil and incubated for 2 weeks prior to sowing.

The seeds were single-seeded and applied with carbofuran insecticide at a rate of $20 \mathrm{~kg}$ ha-1 at the planting hole. Plant spacing was $25 \mathrm{~cm}$ in a row and $75 \mathrm{~cm}$ apart between rows. Fertilizer of urea, TSP, and $\mathrm{KCl}$ at the rate of $150 \mathrm{~kg}$ $\mathrm{ha}^{-1}, 100 \mathrm{~kg} \mathrm{ha}^{-1}$, and $50 \mathrm{~kg} \mathrm{ha}^{-1}$, respectively, were sidedressed after the seeds were sown. The rate of urea was a half of the optimum dozes for the growth of maize hybrid variety for natural non-acidic soil [20]. Reseeding was conducted at seven days after planting to replace nongerminating seeds.

Plant maintenance included row mounting, weeding, and pest and disease controlling. The soil between rows of plants was piled up to the plant rows so that it covered the lower part of the plant stem. The row mounting was performed at seven weeks after seeding to strengthen the plant stand. Weed control was carried out mechanically three, five, and seven weeks after sowing. Insecticide and fungicide were applied preventively every two weeks according to the recommendations. Stem and ear borers were controlled by deltamethrin insecticide in a concentration of $2 \mathrm{ml} . \mathrm{L}^{-1}$, blast and downy mildew were controlled by 2 g.L $\mathrm{L}^{-1}$ mancozeb and propane fungicide.

Harvesting was carried out at full ripeness indicated by more than $75 \%$ of the plant population showed dry, hard, and shiny kernels. The cobs were pulled out of the plant, un-husked, and dried in the sun. The kernels were removed from their ear and counted for the number of kernels per ear. The seed dry weight per plot at a water content of $14 \%$ was measured by a digital balance.

Observation was performed on plant height, number of leaves, stem diameter, ear height, leaf area, leaf greenness, number of rows, ear length, ear weight, ear diameter, number of kernels per row, and yield per plant. The data was analyzed by analysis of variance and the mean separation was performed by the Least Significant Difference (LSD) at $\alpha=5 \%$.

\section{RESULTS AND DISCUSSION}

The characteristics of the coastal land at the experimental site indicated that the soil texture consisted of loamy sand with high sand content (80\%), and low in organic C (2.48\%), P-bray (5.34 ppm), total N (0.19 \%), and exchangeable $\mathrm{K}(0.19 \mathrm{me} / 100)$. These characteristics attributed that the soil was low in fertility.

Data from the Meteorological, Climatological and Geophysical Agency showed that the average temperature during the study ranged from $26.8^{\circ} \mathrm{C}$ to $27.8^{\circ} \mathrm{C}$, which is suitable for growth and yield of maize. The average rainfall per month varies from $92 \mathrm{~mm}$ to $459 \mathrm{~mm}$. The temperature required for the growth of maize plants is $15^{\circ} \mathrm{C}-32^{\circ} \mathrm{C}$ [21]. The humidity during the study is $86 \%$ according to $82 \%$. The ideal rainfall for maize is generally 500-1200 mm per month [21].

\subsection{Analysis of Variance}

There was no interaction effect between the types of manure and the hybrids on growth and yield of maize. The manure treatment significantly affected the vegetative growth, including plant height, number of leaves, stem diameter, ear height, and leaf area. The applied fertilizer of 20 ton.ha ${ }^{-1}$ did not affect the yield. This may be due to the single season experiment. Several studies on the application of manure showed that the effect of manure on increasing crop production was a long-term effect. A significant increase in maize yield when fertilizer was applied over 4 years [22]. Application of poultry manure over 3 years increased tuber production of potato [23].

The hybrids were significantly affected leaf number, stem diameter, ear height, leaf green, the number of rows, ear length, ear diameter, number of kernel per row, and the plant yield (Table 1).

\subsection{Effect of Manure Types on Growth and Yield of Maize Hybrid}

Manure application significantly increased the vegetative growth of maize. Compared to control, application of poultry manure, cow manure, or goat manure increased plant height, number of leaves, stem diameter, and ear height of maize plant. The average value of plant height, number of leaves, stem diameter, and ear height with manure were higher than without manure. The increase was about similar among the types of manure. There was a tendency that goat manure was better in increasing the growth of maize plant in coastal lands than the other types. The leaf area observed in goat manure was higher than that in other treatments. The application of poultry manure or cow manure did not increase the leaf area (Table 2). 
Plant height usually indicates plant growth. However, the maize plants which are too tall will easily collapse. An increase in plant height must be followed by the increase in stem diameter. In this study, the application of manure significantly increased stem diameter.

Table 1. F value resulted from analysis of variance for growth and yield variables

\begin{tabular}{|l|c|c|c|r|}
\hline \multirow{2}{*}{ Variable } & \multicolumn{3}{c|}{ F value } & \multirow{2}{*}{ CV(\%) } \\
\cline { 2 - 5 } & Manure Type & Genotype & Interaction & \multicolumn{1}{c|}{7.74} \\
\hline Plant height & $7.75 * *$ & $0.43 \mathrm{~ns}$ & $1.04 \mathrm{~ns}$ & 5.95 \\
\hline Number of leaves & $8.92 * *$ & $6.83 * *$ & $0,68 \mathrm{~ns}$ & 10.73 \\
\hline Stem diameter & $5.08 * *$ & $15.20 * *$ & $0.69 \mathrm{~ns}$ & 10.82 \\
\hline Ear height & $7.95 * *$ & $6.09 * *$ & $0.77 \mathrm{~ns}$ & 11,80 \\
\hline Leaf area & $4.90 * *$ & $2.90 \mathrm{~ns}$ & $2.00 \mathrm{~ns}$ & 9.39 \\
\hline Leaf greenness & $1.95 \mathrm{~ns}$ & $5.50 * *$ & $1.11 \mathrm{~ns}$ & 10.84 \\
\hline Number of grain row & $0.96 \mathrm{~ns}$ & $5.11 * *$ & $1.29 \mathrm{~ns}$ & 8.31 \\
\hline Ear length & $0.11 \mathrm{~ns}$ & $6.61 * *$ & $0.81 \mathrm{~ns}$ & 19.76 \\
\hline Ear weight & $0.57 \mathrm{~ns}$ & $2.50 \mathrm{~ns}$ & $1.38 \mathrm{~ns}$ & 7.23 \\
\hline Ear diameter & $1.06 \mathrm{~ns}$ & $5.27 * *$ & $1.91 \mathrm{~ns}$ & 15.29 \\
\hline Number of kernel per row & $0.78 \mathrm{~ns}$ & $8.53 * *$ & $3.34 \mathrm{~ns}$ & 19.39 \\
\hline Yield & $1.99 \mathrm{~ns}$ & $5.33 * *$ & $1.97 \mathrm{~ns}$ & 19 \\
\hline
\end{tabular}

Note : $\mathrm{ns}=$ not significantly difference on the $\mathrm{F}$ test at $\alpha=5 \%, * *=$ significantly difference on the $\mathrm{F}$ test at $\alpha=1 \%$

Table 2. Growth performances of maize under different application of manure

\begin{tabular}{|l|c|c|c|c|c|}
\hline \multicolumn{1}{|c|}{ Type of Manure } & $\begin{array}{c}\text { Plant height } \\
(\mathbf{c m})\end{array}$ & $\begin{array}{c}\text { Number of } \\
\text { Leaves }\end{array}$ & $\begin{array}{c}\text { Stem } \\
\text { Diameter } \\
(\mathbf{m m})\end{array}$ & Ear Height $(\mathbf{c m})$ & $\begin{array}{c}\text { Leaf Area } \\
\left(\mathbf{c m}^{2}\right)\end{array}$ \\
\hline Control & $170.34 \mathrm{~b}$ & $9.83 \mathrm{~b}$ & $20.67 \mathrm{~b}$ & $95.04 \mathrm{~b}$ & $503.55 \mathrm{~b}$ \\
\hline Poultry manure & $190.66 \mathrm{a}$ & $10.82 \mathrm{a}$ & $23.73 \mathrm{a}$ & $113.45 \mathrm{a}$ & $487.96 \mathrm{~b}$ \\
\hline Cow manure & $185.65 \mathrm{a}$ & $10.76 \mathrm{a}$ & $23.52 \mathrm{a}$ & $112.33 \mathrm{a}$ & $494.35 \mathrm{~b}$ \\
\hline Goat manure & $197.62 \mathrm{a}$ & $11.08 \mathrm{a}$ & $24.24 \mathrm{a}$ & $116.23 \mathrm{a}$ & $571.75 \mathrm{a}$ \\
\hline
\end{tabular}

Note : Means within the same column followed by the same letter are not significantly different according to LSD ( $\mathrm{p} \leq 0.05$ )

Manure provides additional nutrients while improving the physical, chemical, and biological properties of the soil. It is well known that the coastal soils with high sand content are very poor in nutrients content and water retention. The application of manure increased phosphorus, potassium and C-organic content in soil significantly (Table 3). The increase of soil nutrient content was about similar with any types of manure as the nutrient content in manure was comparable among them (Table 4).

Table 3. Soil nutrient content before and after application of manure*

\begin{tabular}{|l|l|c|c|c|c|}
\hline \multirow{2}{*}{ Nutrient content } & \multirow{2}{*}{ Method } & \multirow{2}{*}{$\begin{array}{c}\text { Before } \\
\text { Application }\end{array}$} & \multicolumn{3}{c|}{ After Application } \\
\cline { 4 - 7 } & & 0.19 & 0.20 & 0.18 & 0.17 \\
\hline N-total (\%) & Kjeldahl & 5.34 & 9.56 & 9.11 & 10.47 \\
\hline P (ppm) & P-Bray & 0.19 & 0.27 & 0.24 & 0.25 \\
\hline K (me 100 g-1) & Destilasi & 2.48 & 3.43 & 3.87 & 3.03 \\
\hline C-Organik (\%) & Walkey and Black & & & Cow \\
\hline
\end{tabular}

Note *: Analyzed by the Laboratory of Soil Science, Faculty of Agriculture, the University of Bengkulu

Among the three types of manure, the macronutrient content of poultry manure was the highest. However, the goat manure supported for better plant growth. The result of soil analysis at the end of the experiment revealed that the exchangeable $\mathrm{P}$ in the soil applied with goat manure was almost double as high as that of without manure application. The increase of exchangeable $\mathrm{P}$ in the soil might be the cause of vegetative growth improvement. The result was similar to the finding of Talip and Sison [24] that application of 10 ton.ha ${ }^{-1}$ goat manure increased plant height, the number of leaves, and leaf area of maize. Goat manure is known to have higher $\mathrm{K}$ and $\mathrm{Ca}$ content than other types of manure [25]. Many studies proved the necessity of $\mathrm{Ca}^{+2}$ ions in auxin-induced 
plant cell elongation [26]. The soil cores $(0$ to $15 \mathrm{~cm})$ contained high contents of phosphor (376-435 mg P kg 1) indicating substantial accumulation after a manure application continuously [27].

It is believed that the improvement in plant growth is not solely as a result of the addition of macronutrients but due to the simultaneous improvement in soil fertility. The increase of plant growth in goat manure treatment was also thought to have occurred due to higher absorption of phosphorus. The result of plant tissue analysis on goat manure application showed higher $\mathrm{P}$ content $(1.36 \%)$ compared to that of control (1.2\%). Meanwhile, the leaf $\mathrm{P}$ status in chicken or cow manure was similar to control, $1.16 \%$, and $1.17 \%$, respectively (data was not presented, leaf P status was analyzed by Laboratory of Soil, Plants, Fertilizer, and Water of the Center for Agricultural Technology Application - BPTP Bengkulu). All yield and yield components were not affected by the application of manure. The average maize yields obtained in manure applied plots were not significantly different from the control.

Table 4 Nutrients content observed from different manures*

\begin{tabular}{|l|c|c|c|}
\hline \multirow{2}{*}{$\begin{array}{c}\text { Nurtrien } \\
\text { Content }\end{array}$} & $\begin{array}{c}\text { Poultry } \\
\text { Manure }\end{array}$ & $\begin{array}{c}\text { Cow } \\
\text { Manure }\end{array}$ & $\begin{array}{c}\text { Goat } \\
\text { Manure }\end{array}$ \\
\cline { 2 - 4 } & \multicolumn{3}{|c}{$\ldots \ldots \ldots . . \ldots \ldots \ldots \ldots \ldots$} \\
\hline Nitrogen & 1.36 & 0.93 & 0.98 \\
\hline Phosphor & 1.09 & 0.73 & 0.76 \\
\hline Kalium & 0.81 & 0.67 & 0.68 \\
\hline C-Organik & 11.46 & 12.29 & 10.84 \\
\hline
\end{tabular}

\subsection{Growth and Yield of Maize in Coastal Land}

The four maize hybrids evaluated in this study were new maize hybrids selected for adaptive to coastal lands. The hybrids were developed from the crosses between the Bengkulu local lines and the gamma ray radiation mutant lines. The Bengkulu local lines are drought tolerant while gamma ray radiation mutant lines are tolerance to various abiotic stresses.
The hybrids evaluated in this study were the hybrids developed from crosses of local lines to droughttolerant mutants. Therefore, they are expected to be able to adapt well to the coastal land. The adaptability of the four hybrids to coastal lands can be evaluated by the performance of their growth and yield. There was variation in growth and yield of the four hybrids on the coastal land. The CT 30 genotypes had the most vigorous appearance with the largest stem diameter compared to the others (Table 5). The stem diameter of CT 30 was even bigger than the CT 9 hybrid which has been shown to have the best yield stability in several marginal land locations [7]. However, the number of leaves on CT 30 was less than CT 43 and CT 50.

The hybrid CT 34 grew better with higher number of leaves and higher leaf greenness. Leaf greenness indicates the amount of chlorophyll in the leaves, so that the two variables may correlate with for the yield. In the study on the application of $\mathrm{N}$ fertilizer, Argenta et al [28] figured out that $\mathrm{N}$ increased the leaf chlorophyll content followed by the increase of maize yield.

The ear height ranged from $101 \mathrm{~cm}$ to $121 \mathrm{~cm}$ (Table 5). The height of the ear is still quite good in maintaining the plant upright and not easily logged, and cob harvesting is easily conducted [30].

In general, all hybrids applied with any type of manure exhibited good growth although the nutrient content of the manure was known relatively low. Several studies indicated that repeated manure application could increase soil nutrients. Low rate but repeated applications of poultry manure gave benefit to potato tuber yield and the soil biological properties, although the soil physical properties did not drastically change. After three annual applications of poultry manure, soil $\mathrm{P}, \mathrm{K}, \mathrm{B}, \mathrm{Cu}, \mathrm{Na}, \mathrm{S}$, and $\mathrm{Zn}$ increased significantly [23].

Growth performance in coastal area varied among hybrids. The CT 30 had the most vigorous appearance with the largest stem diameter (Table 5). The growth superiority of CT 30 was also obtained in previous studies at several locations [7]. However, the number of leaves on CT 30 was less than that of CT 43 or CT 50 . The number of leaves was the trait often positively correlated with yield.

Table 5. Mean growth performances of 4 maize hybrids in coastal land

\begin{tabular}{|c|c|c|c|c|}
\hline Hybrid & $\begin{array}{c}\text { Stem Diameter } \\
(\mathbf{m m})\end{array}$ & Number of Leaves & Leave Greeness & $\begin{array}{c}\text { Ear Height } \\
(\mathbf{c m})\end{array}$ \\
\hline CT16 & $24.03 \mathrm{~b}$ & $10.10 \mathrm{~b}$ & $41.53 \mathrm{~b}$ & $121.09 \mathrm{a}$ \\
\hline CT30 & $26.53 \mathrm{a}$ & $10.35 \mathrm{~b}$ & $42.19 \mathrm{~b}$ & $108.57 \mathrm{~b}$ \\
\hline CT34 & $20.98 \mathrm{c}$ & $10.94 \mathrm{a}$ & $47.02 \mathrm{a}$ & $101.41 \mathrm{~b}$ \\
\hline CT50 & $20.62 \mathrm{c}$ & $11.11 \mathrm{a}$ & $41.16 \mathrm{~b}$ & $106.57 \mathrm{~b}$ \\
\hline
\end{tabular}

Note : Means within the same column followed by the same letter are not significantly different according to LSD ( $\mathrm{p} \leq 0.05$ )

The yield component and the yield performance varied among hybrids. In general, the best hybrid based on ear length, ear diameter, number of grains, and number of grains per row was exhibited by CT30, although its grain yield did not differ significantly from CT34, and CT50 (Table 6). Based on the vegetative growth (stem diameter) and yield components, CT30 performed better than other hybrids evaluated on the coastal land, 
although its yield was not different from CT34 or CT50. CT30 hybrids have genetically high yield stability, however, the yield in this study were not better than the previous results.

Table 6. Mean performances of yield and yield components of 4 maize hybrids in coastal land

\begin{tabular}{|c|c|c|c|c|c|}
\hline Treatments & Ear length $(\mathbf{c m})$ & $\begin{array}{c}\text { Ear diameter } \\
(\mathbf{m m})\end{array}$ & Number of row & $\begin{array}{c}\text { Number of } \\
\text { grain per row }\end{array}$ & $\begin{array}{c}\text { Yield } \\
(\mathbf{g})\end{array}$ \\
\hline CT16 & $18.13 \mathrm{a}$ & $38.32 \mathrm{~b}$ & $12.05 \mathrm{a}$ & $22.80 \mathrm{c}$ & $98.60 \mathrm{~b}$ \\
\hline CT30 & $17.36 \mathrm{a}$ & $42.01 \mathrm{a}$ & $12.78 \mathrm{a}$ & $30.88 \mathrm{a}$ & $118.30 \mathrm{a}$ \\
\hline CT34 & $16.18 \mathrm{~b}$ & $42.24 \mathrm{a}$ & $12.05 \mathrm{a}$ & $27.16 \mathrm{~b}$ & $124.19 \mathrm{a}$ \\
\hline CT50 & $15.89 \mathrm{~b}$ & $39.38 \mathrm{a}$ & $10.88 \mathrm{~b}$ & $29.61 \mathrm{ab}$ & $135.40 \mathrm{a}$ \\
\hline
\end{tabular}

Note : Means within the same column followed by the same letter are not significantly different according to LSD ( $\leq 0.05$ )

The application of manure of 20 ton.ha' ${ }^{-1}$ could not significantly increase the yield of hybrids. Manure is less effective for increasing soil fertility in short time. However, there were indications that there was slightly increase in of phosphorus absorption leading to increase in the leaf $\mathrm{P}$ status. Increasing leaf $\mathrm{P}$ status might be attributable to the increase in yield. The finding was in harmony with the results of [29] that repeated manure application improved the yield. The increase in maize yield due to the addition of a continuous manure was due to organic fertilizers over three years supported the residual mineralization of soil nutrients after harvest with an increase in total nitrogen $(\mathrm{N})$, available phosphorus (P), and soil organic matter (SOM) [22].

Adequate levels of $\mathrm{N}, \mathrm{P}$, and SOM after the maize harvest played an important role in stable high yields in the next season. Other studies suggest that organic fertilizer is typically mineralized within a few growing seasons. To achieve a sustainable and stable yield increase, organic fertilizer should therefore be applied in consecutive years [15].

\section{CONCLUSION}

There was no difference in the response of maize to various types of manure. Goat manure was the best for improving the vegetative growth of maize in coastal land. The three types of manure did not increase the yield of hybrid maize. Of the 4 hybrids tested, CT 30 performed the best in the coastal land.

\section{ACKNOWLEDGMENT}

The authors would like to thank to Faculty of Agriculture, University of Bengkulu for the funding support of this research in the year of 2020.

\section{REFERENCES}

[1] C.R. Dowswell, R.L. Paliwal and R.P. Cantrell. Maize in The Third World. Routledge. New York. 2018

[2] L.K. Murdia, R. Wadhwani, N. Wadhawan, P Bajpai, S. Shekhawat, "Maize Utilization in India: An Overview", American Journal of Food and Nutrition, vol. 4, no. 6, pp. 169-176, 2016.

[3] P. Ranum, J.P. Peña -Rosas, and M.N. Garcia-Casal, Global maize production, utilization, and consumption, Ann.N.Y.Acad.Sci., vol. 1312, no. 1, pp. 105-112, 2014.

[4] Statistic Indonesia, Foreign Trade Statistical Bulletin:Imports, Jakarta, Indonesia; BPS Statistic Indonesia, 2018.

[5] E.C. Omondi, J.B. Norton and D.S. Ashilenje, Performance of a local open pollinated maize vaariety and a common hybrid variety under intensive small-scale farming practices, Afr. J. Agric. Res., vol. 9, no. 11, pp. 950-955, 2014.

[6] D.K.S. Swastika, F. Kasim, K. Suhariyanto, W. Sudana, R. Hendayana, R.V. Gerpacio, and P.L. Pingali. Maize in Indonesia: Production Systems, Constraints, and Research Priorities. Mexico, D.F.: CIMMYT, 2004

[7] Rustikawati, A. Romeida, E. Suprijono and C. Herison, Growth performance and AMMI yield stability analysis of five new maize hybrid populations, International Journal on Advanced Science, Engineering and Information Technology, vol. 10, no. 1, pp. 344-350, 2020.

[8] Rustikawati, E. Supriyono, A. Romeida, C. Herison, S.H. Sutjahjo, Identification of M4 gamma irradiated maize mutant based on RAPD markers, Agrivita, vol. 34, no. 2, pp. 161-165, 2012.

[9] D. Bhumbla and I. Abrol, Saline and sodic soils. In Soil and Rice pp 719-738. IRRI. Manila, 1978

[10] S.A. Haque, Salinity problems and crop production in coastal regions of bangladesh, Pak. J. Bot., vol. 38, no. 5, pp. 1359-1365, 2006. 
[11] B.A.O. Ahmed, M, Inoue, S. Moritani, Effect of saline water irrigation and manure application on the available water content, soil salinity, and growth of wheat. Agricultural Water Management, vol. 97165-170, 2010.

[12] K.M. Hati, A. Swarup, A. K. Dwivedi, A.K. Misra, K.K. Bandyopadhyay, Changes in soil physical properties and organic carbon status at the topsoil horizon of a vertisol of central India after 28 years of continuous cropping, fertilization and manuring. Agriculture Ecosystems and Environment, vol.119, pp. 127-134, 2007.

[13] A. Fares, F. Abbas, A. Ahmad, J. L, Deenik, M, Safeeq, Response of selected soil physical and hydrologic properties to manure amendment rates, levels, and types. Soil Science, vol. 173, 522-533, 2008.

[14] Q. Liang, Effects of 15 years of manure and inorganic fertilizers on soil organic carbon fractions in a wheatmaize system in the North China Plain. Nutr. Cycl. Agroecosyst, vol. 92, 21-33, 2012.

[15] K.C. Uzoma, M. Inoue, H. Andry, H. Fujimaki, A. Zahoor, E. Nishihara, Effect of cow manure biochar on maize productivity under sandy soil condition, Siol Use and Management, vol. 27, no. 2, 205-212, 2011.

[16] H. Kandil, \& N. Gad, Response of tomato plants to sulphur and organik fertilizer. International Journal of Academic Research, vol. 2, no. 3, 204-210, 2010

[17] W. Farhad, M. F. Saleem*, M. A. Cheema and H. M. Hammad, Effect of poultry manure levels on the productivity of spring maize (Zea mays L.), The Journal of Animal \& Plant Sciences vol. 19no. 3, 122-125, 2009

[18] O.T. Ayoola and E.A Makinde, Performance of green maize and soil nutrient changes with fortified cow dung, African Journal of Plant Science, vol. 2, no. 3, pp. 019-022, 2008.

[19] D.F. Uwah \& V.E. Eyo, Effects of number and rate of goat manure application on soil properties, growth and yield of sweet maize (Zea mays L. saccharata Strut), Sustainable Agriculture Research, vol. 3(4) 75-83, 2014.

[20] B. Setyawan, I. Suliansyah, A. Anwar, E. Swasti, Preliminary trial of 11 new hybrid maize genotype to the resistance on Java Downy Mildew (Peronosclerospora maydis), Int. J. Adv. Sci. Eng. Inf. Technol, vol. 6, no. 2, pp. 262-264, 2016.
[21] L. E. Rincón, C.A. Cardona and C. E. Orrego, "Special Requirements: Agricultural and Industrial Infrastructure. Pp 78-117. In S.L. Goldman and C. Kole. Compendium of Bioenergy Plant: Corn. CRC Press. London. 2014

[22] X. Wang, Y. Ren, S. Zhang, Y. Chen, N.Wang, Applications of organic manure increased maize (Zea mays L.) yield and water productivity in a semi-arid region, Agricultural Water Management, vol. 187, pp. 88-98, 2017.

[23] H.W. Rees, T.L. Chow, B. Zebarth, Z. Xing, P. Toner, J. Lavoie, and J.L. Daigle, Impact of supplemental poultry manure application on potato yield and soil properties on a loam soil in northwestern New Brunswick. Can. J. Soil Sci., vol. 94, pp. 153-165, 2014

[24] O.S. Talip and L.C. Sison, Performance of Sweet Corn, Zea mays L. saccharata Applied with Goat Manure and Bio-N, Journal of Multidisciplinary Studies, vol. 6, no. 2, pp. 114-137, 2017

[25] S.O. Ojeniyi, D.A. Akanni and M.A. Awodun, Effect of goat manure on some soil properties and growth, yield and nutrient status of tomato, J. Agric. Sci. vol.15, no. 3, pp. 396-406, 2007.

[26] H-T Cho, Y-N Hong, Effect of calcium channel blockers on the IAA-induced cell elongation of sunflower hypocotyl segments. Journal of. Plant Physiology, vol. 149, 1996.

[27] J.M. Novak, D.W. Watts, P.G. Hunt, K.C. Stone, Phosphorus movement through a coastal plain soil after a decade of intensive swine manure application, Journal of environmental quality, vol. 20, no. 4, pp. 1310-1315, 2000.

[28] G. Argenta, P.R.F. da Silva, L. Sangoi, Leaf relative chlorophyll content as an indicator parameter to predict nitrogen fertilization in maize, Santa Maria vol.34, no. 5, pp. 1379-1387, 2004.

[29] B. J. Zebarth, J. W. Paul, , O. Schmidt, and , R. McDougall, Influence of the time and rate of liquid manure application on yield and nitrogen utilization of silage corn in south coastal British Columbia, Canadian Journal of Soil Science, vol.76, no. 2, pp. 153-164, 1996.

[30] W.A.N.G. Qun, X.U.E. Jun, J.L Chen, Y.H..Fan, G. Q. Zhan, R Z. Xie, and S.K. Li, "Key indicators affecting maize stalk lodging resistance of different growth periods under different sowing dates". Journal of Integrative Agriculture, vol. 19, no. 10, pp. 2419-2428, 2020. 